\title{
Business Entrepreneurship And Education
}

\section{Empreendedorismo empresarial e educação}

\author{
PEDRO ÁLVARO CORREIA PEREIRA \\ IRENE GARCÍA MEDINA \\ PATRICIA MARGARIDA FARIAS COELHO
}

\section{Abstract}

This study is a review of the literature regarding business entrepreneurship and education. The main aim is to study the social and educational factors affecting the creation of self-employment for young people as a contribution to the development of local entrepreneurship, reducing unemployment and leveraging economic development. Of the various social influencers, it was important to understand the role of the family, especially of the parents, in motivating and sustaining the creation of one's own job and in the actions of entrepreneurship. In the same sense, at the educational level, to perceive the consequences of access to new resources that expand and support knowledge and skills acquisition useful for creating one's own job and reducing risk aversion of business activities. Finally, to understand the role of endogenous factors such as intelligence and individual motivation in the pursuit of entrepreneurship activities and their relationship with social and educational influencers.

Keywords: Business Entrepreneurship. Education. Economic development.

\section{RESUMO}

O objetivo principal é estudar os fatores sociais e educacionais que permitem a criação do autoemprego dos jovens como contribuição ao desenvolvimento do empreendedorismo local, reduzindo o desemprego e aproveitando o desenvolvimento econômico. Das várias influências sociais, foi importante compreender o 
papel da família principalmente dos pais na motivação e sustentação para a criação do próprio emprego e nas ações empreendedoras. No mesmo sentido, no nível educacional, se percebe as consequências do acesso a novos recursos que se ampliam e se alicerçam no conhecimento e na aquisição de habilidades úteis para a criação do próprio emprego e para a redução da aversão ao risco das atividades empresariais. Por último, entender o papel dos fatores endógenos, como a inteligência e a motivação individual na busca de atividades de empreendedorismo e a sua relação com os influenciadores sociais e educacionais.

Palavras-chave: Empreendedorismo Empresarial. Educação. Desenvolvimento Econômico.

\section{INTRODUCTION}

The country's economic development is essentially promoted through the private sector activity. The sustainability of this activity is based on environmental factors such as cultural, social, political and economic which endorses entrepreneurship.

It is believed that education especially entrepreneurship education increases the entrepreneurship actions, supporting the promotion and implementation of education actions along the educational system in many of the European member countries, despite this fact, little is known about its impact on students' entrepreneurial competencies and intentions. (EUROPEAN COMMISSION, 2006), how the courses impact students' willingness to engage in entrepreneurial activity and what kind of learning processes are responsible for these effects. (GRAEVENITZ et al., 2010).

The current article tries to fill this gap by identifying the literature review that analyzes social and educational factors that fostering the student young entrepreneurship, as an alternative to finding a job through the creation of self-employment.

As an approach to combat the lack of jobs and precariousness it is important to understand clearly the factors that influence young people to create their company as a reaction to the current employment situation.

Therefore, it is important to understand the factors that influence or trigger entrepreneurship, namely the support environment (family and friends), entrepreneurial experience and capacity, 
resources (financial capacity, economic and socio-cultural support), motivation, entrepreneurship training / education.

This study seeks to analyze the literature regarding the dynamics of the factors social and academic that affect student's entrepreneurship intentionor their commitment to start a new business (KRUEGER, 1993).

\section{LITERATURE REVIEW}

\subsection{Entrepreneurship}

Nowadays, promoting entrepreneurship in education is an essential key for students to take risks, be independent and have confidence in their future work.

To understand the importance of this concept, first, we must know what it means. Entrepreneurship refers to the attitude and aptitude to carry out a project through ideas and opportunities and facing adversities. The term is used, above all, in economics, in which an enterprise is an initiative that assumes an economic risk in order to take advantage of a market opportunity.

Promoting entrepreneurship in children, young people and adults is important to promote their autonomy and overcoming life. The benefits of this practice are multiple: creativity, assertiveness, trust and positive thinking develop. On the other hand, it also improves the ability to resolve conflicts and make decisions.

Without a precise definition a large amount of literature tries to define and explain the essence of entrepreneurship, most of which are based on the works of Schumpeter (1934) and Kirzner (1973), Adekiya and Ibrahim (2016).

The entrepreneurial profile is described by Hisrich (1988, p. 29) as "motivation and personal characteristics". For the establishment of an entrepreneurial profile, must be taken into consideration the characteristics or traits personal possessed by an individual.

The entrepreneur usually appears in the eyes of others as someone guided internally by an unstoppable desire to achieve goals, as someone who seeks excellence. Its strong nature leads him to accept certain risks and to pursue objectives that motivate him. (IBRAHAIM et al., 2002) 
The importance of entrepreneurship to society has been identified and discussed since at least the fifteenth century (SCHUMPETER, 1912). Although the lack of precise consensus, it is unavoidable to agree that it involves a combination of factors, namely resources to produce goods and services and management of that resources and goods to accomplish market demands.

Since the entrepreneurial activities have uncertain results, the process of entrepreneurships involves taking risks by the entrepreneur and it also comprises the creation of a new way of exploiting an opportunity and requires innovative activities (ABREU, 2013).

Research on entrepreneurship has been recently growing (SHEPHERD; DOUGLAS; SHANLEY, 2000), in universities and colleges throughout the world (MARTIN, 2013), governments are supporting it directly and by financing major investments in advice-provision to potential entrepreneurs (MARTIN, 2013), with many countries substantially invested in entrepreneurship education at universities (WALTER, 2016).

Although there is agreement that education and prior entrepreneurial experience should influence the will to become an entrepreneur, there is still few research on their impact on entrepreneurship intentions (KRUGER, 1993; KRUEGER; BRAZEAL, 1994).

\subsection{The significance of families in entrepreneurship}

The family constitutes an important basis for the development of entrepreneurial intentions and behaviors (BRYANT; ZVONKOVIC; REYNOLDS, 2006). Entrepreneurship research often views entrepreneurial parents as a source of entrepreneurship that stimulates entrepreneurial career and behavior of its descendants (LINDQUIST; SOL; VAN PRAAG, 2015), influence the intention to start a business (ALTINAY et al., 2012) and promotes a positive relationship between tolerance of ambiguity and risk-taking propensity (ALTINAY et al., 2012).

Sieger, Fueglistaller and Zellweger (2016) confirm in their study that students with entrepreneurial parents are more likely to intend to become entrepreneurs than students without entrepreneurial parents, the positive effect of parents' entrepreneurship is stronger in the entrepreneurial intentions directly after studies than in en- 
trepreneurial intentions in 5 years after studies, this effect depends on the parents' entrepreneurial performance.

Descendants acquire values, knowledge, and skills in entrepreneurship via exposure to their entrepreneurial parents (WYRWICH, 2015). There is a strong and stable causal association between entrepreneurial intentions and subsequent behavior. "Parents help their children overcome the barriers to entry into self-employment by providing them access to valuable resources, one of which is access to their social networks" (EDELMAN, et. al., 2016).

Although some authors find a non-significant relationship between parents' and offspring's entrepreneurship (FRANCO; HAASE; LAUTENSCHLAEGER, 2010) and others like Zhang et al. (2014) find strong evidence for a negative relationship.

Despite abundant research on the intergenerational transmission of entrepreneurship, a clear answer to the question of how parental entrepreneurship relates to offspring's entrepreneurship has not been found (CRIACO et al., 2017).

\subsection{The university influence on entrepreneurship intention}

The big differences in entrepreneurial intentions might be attributed to environmental factors, in particular to the entrepreneurial education and support at the university level. It is very plausible, however, that the different levels of entrepreneurial culture in the universities are at least partly responsible for the differences in entrepreneurial activity after graduation (FRANKE; LUTHJE, 2004).

The university is expected to provide leadership in entrepreneurial and creative thinking, and action across the education, research and engagement domains (ABREU et al. 2016; MENDONÇA NETO; VIEIRA; ANTUNES, 2018).

The university investment in the entrepreneurship education has a positive effect on the number of students who found their own business (CHOI et al. 2017), this effect isn't confine to immediate actions as it's increases the long-term probability of starting a firm as well as entrepreneurial incomes (ELERT et al., 2015; PREMAND, 2016).

The more students become involved in entrepreneurship classes, the more consistent their entrepreneurial intentions become, 
and in most cases, the ideas of creating a business take place in the academic context (SIEGER; FUEGLISTALLER; ZELLWEGER, 2016).

Students with courses in entrepreneurship have stronger entrepreneurial intentions and are more likely to start a new business than students without any training (KURTZID; MOEN, 1997), also these students would become more effective at identifying opportunities and improving both the number of ideas generated and the degree of innovation of these ideas (DETIENNE; CHANDLER, 2004).

In others words, the entrepreneurship education led to a significantly improvement on student learning outcomes, student behavior and attitudes (KIRKLEY, 2017; MORRIS et al. 2017; OLUGBOLA, 2017), it will possibly impact positively on pro-entrepreneurial attitudes of students (SOUITARIS et al., 2007; MARESCH, D. et al., 2015; OLUGBOLA, S., 2017), who might be willing to engage in entrepreneurship activities, but do not have the business skills or experience to take part in them (ABREU; GRINEVICH, 2013; LYONS; ZHANG, 2017), a widespread phenomenon, which is not limited to a category of schools (ASTEBRO et al., 2012).

As students are at the beginning of their careers after graduation, this may be one of the best times to influence them to continue as entrepreneurs (JANSEN et al., 2015), the lack of entrepreneurship experience enhances the relationship between the education and subsequent entrepreneurial activity comparing with individuals with prior entrepreneurship experience, although both aspiring and existing entrepreneurs may benefit from such programs if they provide access to novel resources and capabilities (LYONS; ZHANG, 2017).

Martin et al., (2013) investigation results were supportive of the notion that entrepreneurship can be influenced by entrepreneurship education, other authors found that skills, and competences can be shaped by education(MARESCH et al., 2015; LYONS; ZHANG, 2017), besides the learning benefits, the program provides networking to participants (LYONS; ZHANG, 2017).

Kirkwood et al. (2014), found that the majority of students who enroll on entrepreneurship education perceived they had gained immediate value not only by entrepreneurship knowledge and skills, but also by confidence, a sense of reality and practical solutions. The authors also found that a smaller proportion of students had 
gained future value, through future ideas and networking and these educational benefits are not only important for an entrepreneurial career but could have wider application in career choices beyond entrepreneurship.

In opposite direction, Oosterbeek et al. (2010) measured entrepreneurial intentions among undergraduate university students before and after they completed an entrepreneurship course and found insignificant effect on students' self-assessed entrepreneurial skills and diminishing student motivation to become an entrepreneur after receiving education. However, other studies using the same pretest-posttest design, found evidence that students update their beliefs about their entrepreneurial aptitude after taken the entrepreneurship course.

In particular, students who are uncertain about their entrepreneurial aptitude before taken the course were able to determine more clearly whether or not they are suited to entrepreneurship, helping them make a better assessment of which career is most suitable (GRAEVENITZ et al., 2010; FERREIRA; VIEIRA, 2013), also found a positive correlation between individual's confidence in his ability to successfully perform entrepreneurial roles and tasks and intentions to start a business (SHINNAR et al., 2014).

Inspiration is the program-derived benefit that raises entrepreneurial attitudes and intentions (SOUITARIS et al., 2007). The contradictory results on the relationship between entrepreneurship education and the creation of new businesses in the previous studies may be partly due to the difficulty of finding an accurate measure of different types of supportive activities (MARTIN et al., 2013), the negative effect on the propensity of creating their own employment, could be related with a not well-tailored educational system to provide students the right skills and confidence in setting up their own business and with student reluctance to be self-employed in country's socio-economic and regulatory environment ambiguity (HABIBOV et al., 2017).

The mixes of positive and negative effect of entrepreneurship education which are related with environmental conditions, requires considering the environmental conditions particularly the country's 
institutional environment for a better understanding of the entrepreneurship education results (WALTER, 2016).

This relationship, places universities as supporting elements of strategies to make countries' economies more innovative, however, policymakers should be aware that universities and their entrepreneurial responsibility can only be stretched to a certain level,in which universities assume their role of educating, innovating and making their contributions to society ever more visible (JANSEN et al., 2015).

When universities offer resources facilitating the entrepreneurship training, they are increasing the knowledge of the benefits associated with a career in entrepreneurship, by giving students the required technical and managerial skills, will lead them to a favorable attitudinal disposition towards private ownership of business (ADEKIYA; IBRAHIM 2016).

\subsection{Education in the personal and environmental context}

Personality traits influence entrepreneurship and the intentions of starting a new business (NGA; SHAMUGANATHAN, 2010), the endogenous factors such as, ability, intelligence, and motivation may potentially influence both educational attainment and choice of self-employment (HABIBOV et al., 2017), factors which in terms of experience and training are determinants in the decision to remain self-employed, were attraction depends on their perception that it will lead to desirable outcomes (BARBA-SÁNCHEZ; ATIENZA-SAHUQUILLO, 2017).

Besides that, the entrepreneurship experience reinforces the relation between education and subsequent entrepreneurial activity (LYONS; ZHANG, 2017). Increasing the attractiveness of entrepreneurship education can lead to risk aversion becoming a positive force in promoting entrepreneurship, even some risk-averse people, which have been considered inherently inadequate to entrepreneurship, may indeed be well-suited to this occupation (HSIEH et al., 2017), many of them are willing to undertake risks and challenges of entrepreneurship (PAPULOVÁA; PAPULA, 2015).

The entrepreneurial training can be used as a precursor to student's entrepreneurial intentions (ADEKIYA; IBRAHIM 2016), 
which are evaluated on the GUESS study, the study found that $80.3 \%$ of all students intend to become employees directly after studies but almost $40 \%$ of all students that took part in the survey want to be an entrepreneur 5 year after completion of studies.

Obviously, most students prefer organizational employment directly after studies, and many then plan to swing to an entrepreneurial career path within the next 5 years. (SIEGER; FUEGLISTALLER; ZELLWEGER, 2016), the study also found that entrepreneurial intentions are weaker on females, representing $36.6 \%$ directly after studies but only $10.8 \% 5$ years later and varies across field of study and countries. (SIEGER; FUEGLISTALLER; ZELLWEGER, 2016).

Kirkwood et al., (2014) also suggests slight discrepancies between male and female students' reflections on the value of entrepreneurship education. In general, female students noted the different educational values less frequently than male students.

\subsection{Cultural and Society Influences}

Adekiya and Ibrahim (2016) assume that the cultural value of one individual, in combination with his skills and ability are essential in the development of entrepreneurships intentions, if students are made to believe that a career in entrepreneurship can give them the impetus for self-fulfillment, this belief is likely to be translated into a significant intention to engage in entrepreneurial venture after graduation.

Finally, there is very substantial evidence supporting the claim that entrepreneurial activity has positive long-run economic consequences in terms of wealth, productivity, and growth (BJORNSKOV; FOSS, 2016)

\section{Conclusions}

We can conclude that we are facing a paradigm shift in the field formative-academic, and that achieve a entrepreneurial culture requires a broad and adequate approach in where the student participates in their own learning, let the role of actors and become authors, the teacher being a guide for knowledge building and competence development, thus shortening the distance between learning and experience, favoring a permanent bond with productive organizations. 
A close contact between companies, entrepreneurs and their stories; since the university-company relationship represents an opportunity for learners to gain experience in practice, learn about the path traveled by other entrepreneurs, their limitations and problems, and how they managed to overcome these challenges.

Although there is no unanimity, the various authors support the influence of the family, especially the parents, in the creation of self-employment, as well as the importance of education in the acquisition of knowledge and in the development of useful skills for the creation of one's own employment and consequent reduction of aversion risk in the pursuit of business activities.

The relevance of these influencers appears to be associated with the endogenous factors of each individual such as age, gender, experience, intelligence or aptness for the pursuit of entrepreneurship activities.

Another important fact is revealed in the GUESS study, where it is pointed out that the majority of respondents show preference in working for others in the first 5 years, however, indicates that $40 \%$ shows an intention to develop their own activity after this period with predominance for males.

The lack of unanimity about the influence of social and educational factors on young entrepreneurship can be related to the difficulty in using objective evaluation tools in the analysis of these variables, with multivariate educational systems, with the economic, institutional and cultural environment of each region and with their attitude towards entrepreneurship complemented by institutional support measures.

Consequently, future research should seek to harmonize and isolate these factors in order to have a more coherent and accurate analysis of social and educational factors in the leverage of young entrepreneurship.

\section{REFERENCES}

ABREU, M., DEMIREL, P., GRINEVICH, V., KARATAS-OZKAN, M. Entrepreneurial practices in research-intensive and teaching-led universities. Small Bus Econ 47, 695-717.2016.

ABREU, M., GRINEVICH, V. The nature of academic entrepreneurship in the UK: Widening the focus on entrepreneurial activities. Research Policy, 42, 408-422. 2013. 
ADEKIYA, A., IBRAHIM, F. Entrepreneurship intention among students. The antecedent role of culture and entrepreneurship training and development. The International Journal of Management Education. 2016.

ALMEIDA A., CORREIA P. When Economic Environment is Hostile: Entrepreneurial Intention in a Small Tourist Remote Economy. In: Abreu A., Liberato D., González E.A., Garcia Ojeda J.C. (eds) Advances in Tourism, Technology and Systems. ICOTTS 2020. Smart Innovation, Systems and Technologies, vol 209. pp. 328-340. Springer, Singapore. 2021. Available in: https://doi.org/10.1007/978-981-33-4260-6 29. Acess 25 abr. 2021.

ALTINAY, L., MADANOGLU, M., DANIELE, R., LASHLEY, C. The influence of family tradition and psychological traits on entrepreneurial intention. International Journal of Hospitality Management 31, 489-499. 2012.

ASTEBRO, T., BAZZAZIAN, N., BRAGUINSKY, S. Startups by recent university graduates and their faculty: implications for university entrepreneurship policy. Research Policy 41, 663 -677. 2012.

BARBA-SÁNCHEZ, V., ATIENZA-SAHUQUILLO, C. Entrepreneurial motivation and self-employment: evidence from expectancy theory. International Entrepreneurship and Management Journal 13, 1097-1115. 2017.

BJØRNSKOV, C., FOSS, N. Institutions, Entrepreneurship, and Economic Growth: What Do We Know and What Do We Still Need to Know. The Academy of Management Perspectives, Vol. 30, No. 4, 08.2016, p. 292-315. 2016.

BRYANT, B. K., ZVONKOVIC, A. M., REYNOLDS, P. Parenting in relation to child and adolescent vocational development. Journal of Vocational Behavior, 69(1), 149-175. 2006.

CHOI, K., PARK, J., CHO, D., CHU, H. The Impact of University Support on the Creation of Student Entrepreneurs: Evidence from South Korea. Entrepreneurship Research Journal 20170010. 2017.

CRIACO, G., SIEGER, P., WENNBERG, K., CHIRICO, F., MINOLA, T. Parents' performance in entrepreneurship as a "double-edged sword" for the intergenerational transmission of entrepreneurship. Small Business Economics, 49(4), 841-864. 2017.

DETIENNE, D.R., CHANDLER, G.N. Opportunity identification and its role in the entrepreneurial classroom: a pedagogical approach and empirical test. The Academy of Management Learning and Education, 3(3) 242-257. 2004.

EDELMAN, L. F., MANOLOVA, T., SHIROKOVA, G., TSUKANOVA, T. The impact of family support on young entrepreneurs' start-up activities. Journal of Business Venturing, 31(4), 428-448. 2016.

ELERT, N., ANDERSSON, F., WENNBERG, K. The impact of entrepreneurship education in high school on long-term entrepreneurial performance. Journal of Economic Behavior \& Organization 111, 209-223. 2015.

FERREIRA, R. C. A.; VIEIRA, A. M. Trabalho docente e tecnologias da educação: mediação e confluência. Revista de Tecnologia Aplicada, v. 2, n. 3, p. 46-62, 2013. 
FRANKE, N., LUTHJE, C. Entrepreneurial Intentions of Business Students: A Benchmarking Study. International Journal of Innovation and Technology Management, 1/3: 269-288. 2004.

FRANCO, M., HAASE, H., LAUTENSCHLAEGER, A. Students' entrepreneurial intentions: an inter-regional comparison. Education + Training, 52(4), 260-275. 2010.

GRAEVENITZ G., HARHOFFA, D., WEBER, R. The effects of entrepreneurship education. Journal of Economic Behavior \& Organization 76, 90-112. 2010.

HABIBOV, N., AFANDI, E., CHEUNG, A. What is the effect of university education on chances to be self-employed in transitional countries?: Instrumental variable analysis of cross-sectional sample of 29 nations. International Entrepreneurship and Management Journal 13(2), 487-500. 2017.

HISRICH, R. D. The Entrepreneuer in Northern Ireland: Characteristics, Problems, and Recommendations for the future. Journal of Small Business Management; July, 1988.

HSIEH, C., PARKER, S., PRAAG, C. Risk, balanced skills and entrepreneurship. Small Business Economics 48, 287-302. 2017.

IBRAHAIM, A. B. et al. Entrepreneurship educa Entrepreneurship education and training in Canada: A critical assessment, Education \& Training, London, Tomo 44, No. 8/9; p. 421, 2002.

JANSEN, S., ZANDE, T., BRINKKEMPER, S., STAM, E., VARMA, V. How education, stimulation, and incubation encourage student entrepreneurship: Observations from MIT, IIIT, and Utrecht University. The International Journal of Management Education 13, 170-181. 2015.

KIRKLEY, W. Cultivating entrepreneurial behavior: entrepreneurship education in secondary schools. Asia Pacific Journal of Innovation and Entrepreneurship, 11(1), 17-37. 2017.

KIRKWOOD, J., DWYER, K., GRAY, B. Students' reflections on the value of an entrepreneurshipeducation. The International Journal of Management Education 12 (2014) 307-316. 2014.

KIRZNER, I. Competition and Entrepreneurship. The University of Chicago Press. 1973.

KOLVEREID, L., MOEN, O. Entrepreneurship among business graduates: does a major in entrepreneurship make a difference? Journal of European Industrial Training 21, 154-160.1997.

KRUEGER, N. The impact of prior entrepreneurial exposure on perceptions of new venture feasibility and desirability. Entrepreneurship: Theory and Practice. 18 (1), 5-21. 1993.

KRUEGER, N., BRAZEAL, D. Entrepreneurial potential and potential entrepreneurs. Entrepreneurship: Theory and Practice. 18 (3), 91-104.1994.

LINDQUIST, M. J., SOL, J., VAN PRAAG, M. Why do entrepreneurial parents have entrepreneurial children? Journal of Labor Economics, 33(2), 269-296. 2015.

LYONS, E., ZHANG, L. Who does (not) benefit from entrepreneurship programs?. Strategic Management Journal 39, 85-112. 2017.

MARESCH, D., et al. The impact of entrepreneurship education on the entrepreneurial intention of students in science and engineering versus business studies university programs, Technol. Forecast. Soc. Change. 
MARTIN, B.C., MCNALLY, J.J., KAY, M.J. Examining the formation of human capital in entrepreneurship: a meta-analysis of entrepreneurship education outcomes. Journal of Business Venturing 28, $211-224.2013$.

MENDONÇA NETO, O. R., VIEIRA, A. M., ANTUNES, M. T. P. Industrialização da educação, Edtech e prática docente. EccoS - Revista Científica, n. 47, p. 149-170, 2018.

MORRIS, M., SHIROKOVA, G., TSUKANOVA, T. Student entrepreneurship and the university ecosystem: a multi-country empirical exploration. European J. International Management, Vol. 11(1). 2017.

MUNGAI, E. M. E., VELAMURI, S. R. Parental entrepreneurial role model influence on male offspring: is it always positive and when does it occur? Entrepreneurship Theory and Practice, 35(2), 337-357. 2011.

NGA, H.K.J., SHAMUGANATHAN, G. The influence of personality traits and demographic factors on social entrepreneurship start up intentions. Journal of Business Ethics 95, 259-260. 2010.

OLUGBOLA, S. Exploring entrepreneurial readiness of youth and startup success components: Entrepreneurship training as a moderator. Journal of Innovation \& Knowledge 2, 155-171. 2017.

OOSTERBEEK, H., PRAAG, M., IJSSELSTEIN, A. The impact of entrepreneurship education on entrepreneurship skills and motivation. European Economic Review 54, 442-454. 2010.

PAPULOVÁA, Z., PAPULA, J. Entrepreneurship in the Eyes of the Young Generation. Procedia Economics and Finance 34, $514-520.2015$.

PREMAND, P., BRODMANN, S., ALMEIDA, R., GRUN R., BAROUNI, M. Entrepreneur ship Education and Entry into Self-Employment Among University Graduates. World Development 77, 311-327. 2016.

SCHUMPETER, J. The Theory of Economic Development. Harvard University Press, Cambridge. 1934 .

SCHUMPETER, J. Theorie der Wirtschaftlichen Entwicklung. Duncker \& Humblot, Leipzig. 1912.

SHEPHERD, D. A., DOUGLAS, E. J., SHANLEY, M. New venture survival: Ignorance, external shocks, and risk reduction strategies. Journal of Business Venturing, 15(5), 393 -410. 2000.

SHINNAR, R., HSU, D., POWELL, B. Self-efficacy, entrepreneurial intentions, and gender: Assessing the impact of entrepreneur ship education longitudinally. The International Journal of Management Education 12, 561-570. 2014.

SIEGER, P., FUEGLISTALLER, U., ZELLWEGER, T. Student Entrepreneurship 2016: Insights From 50 Countries. St.Gallen/Bern: KMU-HSG/IMU. 2016.

SOUITARIS, V., ZERBINATI, S., AL-LAHAM, A. Do entrepreneurship programs raise entrepreneurial intention of science and engineering students? The effect of learning, inspiration and resources. Journal of Business Venturing 22, 566-591. 2007.

WALTER, S., BLOCK, J. Outcomes of entrepreneurship education: An institutional perspective. Journal of Business Venturing 31, 216-233. 2016. 
WYRWICH, M. Entrepreneurship and the intergenerational transmission of values. Small Business Economics, 45(1), 191-213. 2015.

ZHANG, Y., DUYSTERS, G., CLOODT, M. The role of entrepreneurship education as a predictor of university students' entrepreneurial intention. International Entrepreneurship and Management Journal, 10(3), 623-641. 2014.

Recebido em: 26-1-2021

Aprovado em: 22-7-2021

Avaliado pelo sistema double blind review.

Disponível em http://mjs.metodista.br/index.php/roc 